\title{
IDENTIFIKASI MINAT BELAJAR KELAS XI DAN XII SMA NEGERI 6 MUARO JAMBI PADA PEMBELAJARAN FISIKA
}

\author{
Novri Elisabeth Hutauruk*, Erika \\ Program Studi Pendidikan Fisika, Universitas Jambi \\ *Email : novrielisabeth7@gmail.com
}

DOI: http://dx.doi.org/10.29303/jpft.v5i2.1434

\begin{abstract}
This research was conducted with the aim to find out the description of the attitude of interest in learning towards physics possessed by students in SMA Negegi 6 Muaro Jambi. The design of this research is quantitative research with the instrument used is a questionnaire. The population of this study is 6 Muaro Jambi Public High School and the sample taken is Muaro Jambi 6 Public High School students. Data analysis was performed using the SPSS Application. From this study it can be said that students in Muaro Jambi 6th High School XI and XII have a good interest in learning about Physics, which is as much as $46 \%$.
\end{abstract}

Keywords: attitude; interest in learning; learning outcomes

\section{PENDAHULUAN}

Pendidikan adalah usaha yang dilakukan secara sadar dan didasari. Didalam dunia pendidikan terjadi proses belajar mengajar. Pada proses belajar tentunya peserta didik diharapkan dapat memperoleh hasil yang baik. Tetapi pada kenyataan yang terjadi sering kali hasil belajar yang diperoleh oleh siswa tidak sesuai dengan harapan. Inilah yang menjadi hal dasar yang perlu diperhatikan oleh setiap guru pada saat proses pembelajaran berlangsung (Sobandi, 2019).

Pada kurikulum 2013 (K13) semua mata pelajaran ada di dalam kurikulum tersebut termasuk mata pelajaran Fisika. Pelajaran fisika merupakan pelajaran yang paling banyak peranannya dalam kehidupan sehari-hari. Selain itu juga, pelajaran fisika juga erat kaitannya dengan hal pembuktian suatu konsep atau teori yang sebelumnya ada. Dengan mengetahui pelajaran fisika peserta didik dapat meningkatkan kemampuan berpikir kritis serta menjadi lebih tertarik atau berminat untuk belajar fisika (Widiawati et al. 2019).

Pembelajaran fisika merupakan bagian dari sains yang banyak membahas tentang alam dan gejalanya mulai dari yang bersifat real hingga yang bersifat abstrak. Hal ini disebabkan karena dalam pelaksanaan pembelajaran siswa tidak banyak dilibatkan dalam proses pengkonstruksian suatu konsep dalam pikirannya, siswa juga tidak terlibat untuk mendiskusikan dan menanyakan banyak hal tetapi hanya sekedar mendengar dan mengulangi jawaban-jawaban yang diharapkan. Kenyataan ini membuat siswa senantiasa menghapalkan rumus serta faktafakta dan tentunya membuat siswa menjadi pribadi yang kurang kritis (Rahmawati et al. 2019).

Pembelajaran fisika bertujuan untuk mengembangan konsep pemikiran siswa atau peserta didik agar mampu memecahkan suatu masalah yang berkaitan dengan fisika dalam kehidupan sehari-hari. Pembelajaran fisika pada umumnya banyak tidak disukai oleh siswa karena pelajarannya yang cukup sulit. Namun, pembelajaran fisika dapat dibuat menarik dengan menggunakan berbagai model dan metode pembelajran yang menarik serta kreatif. Pemilihan model dan metode tersebut bertujuan agar siswa atau peserta didik dapat semakin tertarik atau berminat dalam mengikuti pembelajaran fisika (Nopiani et al. 2019).

Pada proses pembelajaran fisika guru harus bisa memilih metode dan model yang 
akan digunakan pada saat mengajar. Pemilihan metode dan model sangat penting karena dapat mempermudah guru dalam menyampaikan materi pelajaran. Pemilihan model dan metode yang efektif dan efisien dapat membuat peserta didik lebih mudah untuk memahami materi yang disampaikan. Sehingga peserta didik juga dapat meningkatkan hasil belajarnya (Febriani et al. 2019).

Hasil belajar merupakan pencapain yang diperoleh oleh peserta didik itu sendiri. Keberhasilan dalam belajar dipengaruhi oleh banyak faktor diantaranya keterampilan, pengetahuan dan sikap. Sikap yang memepengaruhi hasil belajar peserta didik diantaranya ialah minat belajar yang dimiliki oleh peserta didik (Pebiyanti, 2013).

Sikap peserta didik sangat berpengaruh terhadap proses belajar peserta didik. Terdapat dua bentuk sikap yaitu sikap positif dan sikap negatif. Sikap positif merupakan sikap yang dimiliki peserta didik untuk menerima, merespon serta meghargai pada saat proses belajar mengajar berlangsung. Sedangkan sikap negatif merupakan sikap penolakan, menjauhi, serta tidak menyukai pelajaran dalam proses belajar mengajar berlangsung. Sikap yang paling mendasar pada saat proses belajar mengajar berlangsung yaitu sikap minat belajar dari setiap peserta didik.

Minat belajar menurut Slameto (2010) adalah kecendrungan yang dilakukan bahkan yang diingat oleh peserta didik untuk tetap memperhatikan terus menerus secara berkelanjutan pada suatu kegiatan. Tentu saja kegiatan yang diperhatikan bahkan yang dilakukan oleh peserta didik ini disertai dengan kesenangan dan kepuasan tersendiri. Minat sangat besar pengaruhnya terhadap proses belajar. Orang yang tidak memiliki minat pada pelajaran tentunya sulit untuk mencapai keberhasilan belajar secara optimal. Seseorang yang berminat dalam suatu mata pelajaran akan mencapai hasil pembelajaran yang optimal. Oleh karena itu guru harus mampu membangkitkan minat semua siswa untuk mencapai kompetensi yang telah ditentukan. Selain itu dalam proses pembelajaran haruslah diperhatikan hal yang dapat mendorong siswa agar dapat belajar dengan baik atau mempunyai motivasi untuk berfikir dan memusatkan perhatian, merencanakan dan melaksanakan kegiatan yang berhubungan atau menunjang belajar. Untuk itu, dalam merancang program pembelajaran, satuan pendidikan harus memperhatikan ranah afektifnya (Oktalia et al. 2017).

Dimana minat belajar setiap peserta didik berbeda antara siswa yang satu dengan yang lain. Ada siswa yang minat balajarnya tinggi dan ada pula yang rendah (Adha, 2013).Minat siswa dalam hal belajar di dalam kelas bukan hanya dipengaruhi oleh guru yang mengajar melainkan juga pelajaran yang tidak disukai oleh siswa. Salah satu mata pelajaran yang tidak di sukai oleh anak SMA pada saat ini yaitu mata pelajaran fisika. Namun dengan potensi yang dimiliki setiap peserta didik, itulah yang dapat menentukan apakah dia berminat pada pelajara fisika atau tidak (Jaba, 2018).

Adapun tujuan dari penulisan artikel ini adalah untuk mengetahui gambaran sikap minat atau ketertarikan belajar peserta didik kelas XI dan XII di SMAN 6 Muaro Jambi pada mata pelajaran fisika saat proses belajar mengajar.

\section{METODE PENELITIAN}

Pada penelitian ini, peneliti mengguakan desain penelitian kuantitatif. Penelitian kuantitaif merupakan penelitian yang lebih menekankan pada data yang diperoleh yakni berupa angka/numerik. Pada penelitian kuantitatif data yang diperoleh dapat dipercaya karena analisis pada penelitian kuantitatif dilakukan pengujian hipotesis atau teori tertentu. 
Sehingga inilah yang membuat data yang diperoleh tersebut bersifat akurat atau dapat dipercaya. Adapun populasi dari penelitian ini yaitu SMA Negeri 6 Muaro Jambi dan sampel yang diambil yaitu peserta didik kelas XI dan XII SMA Negeri 6 Muaro Jambi.

Pada penelitian ini instrumen yang digunakan adalah instrumen non test. Jenis instrumen non test yang diapakai yaitu angket atau kuisioner. Menurut (Rahayu, 2007) angket merupakan sejumlah pernyataan yang diberikan dan dijawab oleh responden. Angket yang digunakan adalah angket minat belajar siswa atau peserta didik. Intrumen yang peneliti gunakan ialah angket yang diadopasi dari skripsi yang ditulis oleh Sandi Aswara pada tahun 2018. Angket tersebut berisikan 30 pertanyaan dengan menggunakan skala likert. Skala likert yang digunakan adalah skala dengan 5 indikator pilihan jawaban yaitu STS (Sangat Tidak Setuju), TS (Tidak Setuju), RR (Ragu-Ragu), S (Setuju), dan SS (Sangat Setuju). Setelah data didapatkan, teknik analisis data yang digunakan adalah teknik analisis data kuantitatif dengan pendekatan statistik. Pendekatan statistik yang dimaksud yaitu menggunakan SPSS.

\section{HASIL DAN PEMBAHASAN}

Minat belajar pada penelitian ini yang di ukur adalah melalui 4 indikator yakni ketertarikan untuk belajar, perhatian saat belajar, motivasi saat belajar dan pengetahuan. Pada dasarnya setiap manusia memilki sifat dan karakter yang berbedabeda. Menurut Yusep (2017) karakter merupakan bentuk gambaran manusia dalam hal bersikap atau melakukan suatu perbuatan yang sudah ada pada manusia itu sendiri. Karakter juga dapat dimaknai sebagai nilai dasar yang dapat membangun pribadi seseorang.

Minat belajar setiap peserta didik tentunya berbeda beda. Minat belajar dapat dikatakan pula dengan motivasi belajar. Setiap peserta didik memiliki tingkat minat belajar yang beragam. Ada yang memiliki minat belajar yang tinggi, sedang, dan rendah. Untuk itu, hasil untuk penelitian mendeskripsikan minat belajar peserta didik dapat dilihat pada tabel dibawah ini.

Tabel 1. Gambaran sikap minat belajar peserta didik kelas XI dan XII di SMAN 6 Muaro jambi

\begin{tabular}{llll}
\hline Interval & Kategori & Frekuensi & $\begin{array}{l}\text { Persen } \\
(\%)\end{array}$ \\
\hline $30-54$ & $\begin{array}{l}\text { Tidak } \\
\text { baik }\end{array}$ & 0 & 0 \\
$54.1-78$ & $\begin{array}{l}\text { Kurang } \\
\text { baik }\end{array}$ & 1 & 2 \\
$78.1-$ & $\begin{array}{l}\text { Cukup } \\
\text { baik }\end{array}$ & 19 & 38 \\
102 & Baik & 23 & 46 \\
$102.1-$ & Baik & & 14 \\
126 & Sangat & 7 & 100 \\
$\begin{array}{l}150 \\
\text { Jumlah }\end{array}$ & baik & 50 & \\
\hline
\end{tabular}

Dari hasil penelitian dapat kita lihat bahwasannya tidak terdapat peserta didik yang memiliki minat belajar fisika yang tidak baik dengan rentang skor 30-54. Selanjutnya terdapat $2 \%$ peserta didik atau 1 dari 50 sampel penelitian yang memiliki minat kurang baik terhadap mata pelajaran fisika dengan rentang skor 54.1 - 78. Untuk kategori cukup baik dengan rentang 78.1 102 terdapat 19 dari 50 sampel atau $38 \%$. Rentang selanjutnya yaitu 102-126 merupakan kategori baik, yaitu terdapat 23 dari 50 sampel atau $46 \%$. Dan sisanya 7 dari 50 sampel atau $14 \%$ adalah kategori sangat baik dengan rentang skor $126-150$.

Adanya perbedaan kategori yang dimiliki oleh peserta didik dalam minat belajar ini dapat diakibatkan karena pandangan peserta didik terhadap pelajaran fisika. Adapun peserta didik yang memiliki pandangan yang positif terhadap pelajaran fisika, maka peserta didik tersebut juga akan memiliki minat belajar yang baik terhadap pelajaran fisika. Begitu pula sebaliknya, 
apabila peserta didik memandang fisika secara negatif, maka peserta didik tersebut tidak akan memiliki minat belajar fisika yang baik. Dari hasil penelitian, terlihat bahwa peserta didik di SMA Negeri 6 Muaro Jambi memiliki minat belajar fisika yang baik, yaitu terdapat $46 \%$ berada pada kategori baik.

Pada SMAN 6 Muaro jambi, hasil penelitian menunjukkan bahwa peserta didik mayoritas memiliki minat belajar yang baik. Minat belajar yang baik ini tentunya akan memiliki dampak pada keberlangsungan proses belajar mengajar dikelas. Saat peserta didik memiliki minat belajar yang baik, maka peserta didik akan menaruh perhatian terhadap hal yang diminatinya. Namun begitu pula sebaliknya, saat peserta didik memiliki minat belajar yang rendah. Hal itu menandakan bahwa ia tidak menyukai pelajaran tersebut. Saat seseorang tidak menyukai sesuatu, maka ia akan mencari hal hal atau kegiatan lain yang ia sukai. Dengan begitu, peserta didik yang tidak memiliki minat belajar yang baik ini, bisa saja mengganggu temannya saat belajar atau bermain saat berlangsungnya pembelajaran.

Karena minat belajar mempengaruhi hasil belajar, maka saat minat belajar peserta didik ditingkatkan maka hasil belajar peserta didik juga akan meningkat. Begitu sebaliknya, saat minat belajar peserta didik menurun makan hasil belajar peserta didik juga menurun berikut gambaran hubungan antara minat belajar dengan hasil belajar.

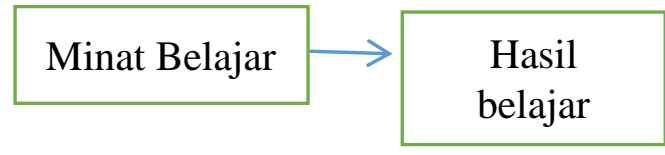

\section{PENUTUP}

Peserta didik yang memandang fisika secara positif, maka akan memiliki minat belajar fisika yang baik. Dan sebaliknya, apabila peserta didik memandang fisika secara negatif, maka ia tidak akan memiliki minat belajar fisika yang baik. Dari penelitian yang dilakukan, dapat kita simpulkan peserta didik di SMA Negeri 6 Muaro Jambi memiliki minat belajar yang baik terhadap mata pelajaran Fisika dan memandang fisika secara positif.

\section{REFERENSI}

Adha, M. M. Sandika. P. \& Berchah. P. 2013. Faktor Yang Mempengaruhi Sikap Peserta Didik Mengikuti Proses Pembelajaran Pkn Di Sma Al-Azhar 3. Jurnal Pendidikan Sekolah Dasar, 2(1), 2.

Febriani, S., Taufik, M., \& Verawati, N. N. S. P. 2019. Pengaruh Model Guided Discovery Learning Dengan Metode Eksperimen Terhadap Hasil Belajar Fisika Peserta Disik MAN 1 Mataram Ditinjau Dari Gaya Belajar VAK. Jurnal Pendidikan Fisika dan Teknologi, 5(1), 74-82.

Jaba, I., \& Palittin, I. D. 2018. Hubungan Minat Belajar Dengan Prestasi Belajar Fisika Siswa Kelas XI IPA SMA Negeri 2 Merauke. MAGISTRA: Jurnal Keguruan Dan Ilmu Pendidikan, 5(1), 062-072.

Nopiani, R., Harjono, A., \& Hikmawati. 2017. Pengaruh Model Pembelajaran Advance Organizer Berbantuan Peta Konsep Terhadap Hasil Belajar Fisika Siswa SMA Negeri 1 Lingsar. Jurnal Pendidikan Fisika dan Teknologi, 3(2), 137-145.

Oktalia, Y., Sakti, I., \& Hamdani, D. 2017. Pengaruh Minat Dan Motivasi Pada Penerapan Model Diskoveri Berbantuan Media Animasi Terhadap Hasil Belajar Fisika Di SMA Negeri 4 Kota Bengkulu. Jurnal Ilmu dan Pembelajaran Fisika, 1(1).

Pebiyanti, D. 2013. Pengaruh sukap belajar dan minat belajar terhadap hasil belajar dalam pembelajaran ekonomi pada SMA, Univ. Tanjungpura, Pontianak. 
Rahayu, Minto. 2007. Bahasa Indonesia Di Perguruan Tinggi. Jakarta: Grasindo

Rahmawati, K. M., Prastowo, S. H. B., \& Bektiarso, S. 2019. Pengembangan Bahan Ajar Fisika Berbasis Scientific Approach Untuk Meningkatkan Kemampuan Berpikir Kritis Siswa Pada Materi Medan Magnet Di SMA. Jurnal Pembelajaran Fisika, 8(2), 80-86.

Slameto. 2010. Belajar dan Faktor- Faktor yang Mempengaruhinya. Jakarta: Rineka Cipta

Soebandi, A. Siti. N. 2016, Minat Belajar Sebagai Determinan Hasil Belajar Siswa (Learning Interest As Determinant Student Learning Outcomes), Jurnal Pendidikan Manajemen Perkantoran, 1(1), 1130.

Widiawati, S., Hikmawati, \& Wahyudi. 2018. Pengaruh Model Pembelajaran Kooperatif Tipe Group Investigation (GI) Terhadap Hasil Belajar Fisika Ditinjau Dari Gaya Belajar Siswa. Jurnal Pendidikan Fisika dan Teknologi, 4(1), 40-48.

Yusep. A. F. 2017. Pembelajaran Wacana Sebagai Landasan Dalam Berliterasi Sastra Untuk Meningkatkan Karakter Siswa. Prosiding Senasbasa http://researchreport.umm.ac.id/index.php/SENAS BASA (Seminar Nasional Bahasa dan Sastra) Edisi 1. 